\title{
UTILIZING COMMUNICATIVE LANGUAGE GAMES TO IMPROVE STUDENTS' SPEAKING ABILITY
}

\author{
Siti Maryam \\ English Teacher, SMPN 4 Praya Barat Daya, Indonesia \\ Corresponding Author Email: maryam@gmail
}

\begin{tabular}{l}
\hline Article Info \\
\hline Article History \\
Received: June 2020 \\
Revised: July 2020 \\
Published: July 2020 \\
\hline Keywords \\
Communicative language \\
games; \\
Speaking skills;
\end{tabular}

\begin{abstract}
This study is aimed at finding the utilizing of communicative language games in improving students' speaking ability at second grade students of SMPN 4 Praya Barat Daya. This study was an action research which comprised two cycles. It involved an English teacher and 24 students of second grade at SMPN 4 Praya Barat Daya. The steps of this study were reconnaissance, planning the actions, implementing and observing the actions, and reflecting the actions done. The data of this study were qualitative and quantitative. The qualitative data were obtained by observing the teaching and learning process during the implementation of the actions and interviewing the students and the English teacher. The data were collected using field notes and interview transcription. The quantitative data were taken by assessing the students speaking ability using pre-test and post-test in the form of students' scores. The research finding shows that the use of the communicative language games is effective to improve students' speaking ability. The games are accompanied with other actions such as using classroom English, applying varied themes, using adequate media, doing language form activities, giving feedback, giving rewards, doing group works and rearranging the students seating arrangement. Therefore, it can be concluded that the use of communicative language games is able to improve students' speaking skills at second grade students of SMPN 4 Praya Barat Daya.
\end{abstract}

How to cite: Maryam, S. (2020). Utilizing communicative language games to improve students' speaking ability. JOLLT Journal of Languages and Language Teaching, 8(3), 251-263, DOI: https://doi.org/10.33394/jollt.v\%vi\%i.2733

\section{INTRODUCTION}

English becomes one of international language which is widely used in the world. As English becomes the global language in the world, people's demand for mastering English is gradually increasing (Mauranen, 2018; Berns, 2019). The ability to communicate in English is very important in the global area because English takes up a very crucial position in almost any sector of use such as business, commerce, academic field, technology, International relations and diplomacy (Bhatia, 2019). In addition, the majority of all resources on the internet are in English. Therefore, learning English is very important.

Realizing the importance of English, the Indonesian government decides that English must be taught officially at schools. Moreover, English has been decided as one of the local content subjects at elementary school and as a compulsory subject at junior high schools and senior high schools (Haerazi, Vikasari, and Prayati, 2019). It is clearly implied in the Indonesian Ministry of Education regulation No. 22/2006 and No. 68/2013 about the scope of the subject in every level of education in the curriculum.

English language teaching consists of four skills to be taught, they are speaking, listening, reading and writing. From these four language skills, speaking might be the most important one to be learned because when students learn a foreign language (Angelini \& Garcia-Carbonell, 2019). They are considered successful once they can communicate 
effectively in their second or foreign language. In line with KD (base competence) of the latest Indonesia 2013 curriculum, the students are required to understand the texts, both spoken and written forms to solve the daily life problems. Thus, students are expected to be able to master English because it is very useful for students in the learning process to achieve learning objectives.

According to Stevick in Fauziati (2002: 126), speaking refers to the gap between linguistic expertise and teaching methodology. Linguistic expertise concerns with language structure and language content. Teaching speaking is not like listening, reading, and writing. It needs habit formation because it is real communication. Speaking needs practicing as often as possible. It is not writing or reading but it must be practiced directly in full expression.

In teaching speaking, a teacher should be able to make an interesting topic and apply the suitable technique (Hidayati, 2019; Buhari, 2019). This can motivate the students to speak more because speaking skill emphasizes students' ability to speak as much as possible. The interesting topic can relate them to their environment and life. In addition, the teacher has to instruct them by not giving a direct correction to their speaking. It fosters them to be confident to explore their idea so that the students are not afraid of making a mistake in speaking the classroom. In teaching speaking, the teacher also has to teach meaningfully (Khodabandeh, 2019).

There are many problems in teaching speaking especially in the classroom. The first, the students are afraid of making a mistake in speaking English. It indicates that the students have a limited vocabulary. The second, the students always do mistakes in grammar and pronunciation aspect. Basically, they only speak English. They do not pay attention to the sentence structure and correct pronunciation. The last, the teacher dominates in teaching the students using Indonesian so it can not increase students' speaking ability.

Those problems also appear in SMP N 4 Praya Barat Daya. Based on an interview with the teacher, some students encountered difficulty in mastering speaking skills. It could be seen from the following phenomena. The students had low speaking ability. It was shown by their being apathetic and inhibited to speak in English. As the result, the students felt afraid of making mistakes when they spoke in English. This condition absolutely obstructed the students' ability in expressing their ideas. Moreover, they tended to be passive in the speaking teaching and learning process. Also, they often pronounced some English words incorrectly when they were asked to speak in English. On the other hand, the students had less opportunity to practice their English orally. It can be seen from the teaching and learning activities which emphasized on doing reading and writing activities and seldom involved speaking activities. Furthermore, environmental and family factors may also influence such as, they came from the village, and they only get English teaching in school.

Based on the phenomena above, the researcher tried to find an effective solution to improve the students' speaking skills. Speaking activities should provide sufficient time for students to practice the target language. The activities also should motivate students, so that they can enthusiastically engage in the learning process. The English teacher also needs to contribute by giving the appropriate feedback that helps students in the activity (Harmer, 1998: 87-88).

In addition, the researcher chose communicative language games to improve the students' speaking skills because communicative language games may give opportunities for students to practice their speaking. The students must speak in order to be able to finish the task. Communicative language games also can make the teaching-learning situation more interesting. The students are not just sitting and listening to the teacher's explanation, but they can interact with their friends and practice their speaking skills. Lastly, communicative language games may boost students' confidence and also motivation in speaking. Considering the problems above and also the benefits of communicative language games in improving 
students' speaking skills, it is necessary to conduct a research entitled "Utilizing Communicative Language Games to Improve Students' Speaking Ability at SMP N 4 Praya Barat Daya Grade VIII".

\section{RESEARCH METHOD \\ Research Design}

This research was an action research study that deals with the use of communicative language games to improve the speaking skill of grade VIII students of SMPN 4 Praya Barat Daya. It focused on the efforts to improve the real condition of the English teaching and learning process. This research was implemented in the form of collaborative action research. The research was conducted collaboratively with the English teacher and the students of grade VIII of SMPN 4 Praya Barat Daya. The team worked together in planning, implementing and reflecting the action as the structured research which was adapted from Kemmis and Mc Taggart (1988). The action research had been conducted through the process as follows.

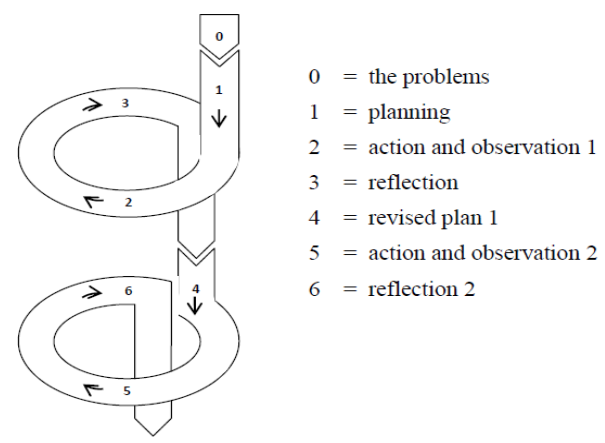

Figure 3.1: The Cycle of Action Research

This figure describes that the researcher and collaborators had identified a problem, formulated a possible solution, implemented the action, and reflected on the outcome of the action. There were two cycles conducted in the research.

\section{Research Setting and Subject}

The setting of the research was at SMPN 4 Praya Barat Daya. It was located on Jalan Ranggagata-Ungga Kecamatan Praya Barat Daya Kabupaten Lombok Tengah. Related to English learning and teaching activities, SMPN 4 Praya Barat Daya had only one English teacher. The English subject is scheduled twice a week for 80 and 120 minutes for each meeting. The school consisted of 3 classes ( 1 class for VII grade, 1 class for VIII grade, and 1 class for IX grade). The average number of students in each class was 24 students.

The facilities supporting the English teaching and learning activities in the classroom were a whiteboard, board markers, an eraser, \pm 24 student tables, \pm 24 student chairs, a teacher table, a teacher chair, and a set of LCD. The subjects of the research are students at SMPN 4 Praya Barat Daya Lombok Tengah Grade VIII in the academic year 2019/2020. The researcher chose the VIII class as the subject of the research with 24 students. The research was conducted in the first semester of the academic year 2019/2020. The observation was done on August $28^{\text {th }}, 2019$ while the research was conducted from August $29^{\text {th }}$ to September $12^{\text {th }}, 2019$. The study took place according to the class schedule in which the English subject was taught twice a week every Wednesday and Thursday. The duration was 80 minutes for Wednesday and 120 minutes for Thursday.

\section{Procedure of Action}

In conducting the action research, the researcher applied Mc Taggart design, which consisted of four phases within one cycle. Those are planning, acting, observing, and reflecting. The first cycle was accomplished to know how the implementation of using 
communicative language games worked out. After finishing the first cycle, if some lacks or problems were found in the result of the first cycle, the researcher would continue to the next cycle as of the satisfies of the finding research. To be more detail about action research phases, the writer illustrates, as follow.

\section{Cycle I}

\section{Planning}

In this phase, the researcher planed what action to be done in applying the communication games in teaching speaking. Firstly, the researcher selected and adjusts the materials with the teachers' annual program based on the SKKD. After determining the material, then the researcher makes a lesson plan that it will be the teacher's guideline in teaching and implementing the games. Other preparations are: preparing the teaching and the research instrument such as sets of pictures, schedule of daily activities, and an observation form. In line with this, the researcher determines the measuring rod of research success. In this case, students are supposed to be able to build their confidence to practice and to express their thought in the form of oral. Here students are also able to interact with people who are known or unknown by them before by using correct expression and structure.

\section{Acting}

After forming the lesson plan, teaching instruments and the research instruments, the researcher implemented the technique by using those preparations. Based on the discussion with the teacher before, the researcher decided to become the teacher, while the English teacher will be the observer who observes the teaching and learning process.

\section{Observing}

The observer observes students' activities, their participation in the class, teachers' performance, and the class situation during the process of teaching and learning. In doing this, the researcher uses a structured observation form that has been prepared by the researcher. In this case, the researcher also notices every single thing by which none information will be missed.

\section{Reflecting}

In the reflecting phase, the researcher discusses with the teacher regarding data that have been collected within the overall activities during the acting to observing. Here, the researcher and the teacher analyze the observation data and the teachers' performance whether the researcher has fully implemented the technique in the action or not. Students' daily worksheets are also analyzed to know whether the implementation of the technique is successful, but if it is unsuccessful, the researcher will continue to the next cycle as the target is reached. Furthermore, data reduction will be used to decide a better plan for the next cycle.

\section{Cycle II}

\section{Planning}

In the planning phase of the second cycle, the researcher will revise the lesson plan based on the problem faced by students within the first cycle. Here the researcher reselects the material and reforms the evaluation and the teaching instrument to improve indicators that have not been reached yet.

\section{Acting}

It is similar to the acting phase at the first cycle in which the revised lesson plan will be implemented in teaching English in the classroom. The three-phase technique is used in accomplishing the teaching process. Expressions and vocabulary are given to the students, 
together with these communicative language games are also implemented within the learning process by using the selected material.

\section{Observing}

In this phase, the researcher observes the students' response, participation, and achievement which are found during the teaching and learning process. The researcher uses an observation form that has been formed by the researcher to collect the data.

\section{Reflecting}

In this phase, the researcher evaluates students' progress in their speaking ability after teaching by using communication games. The researcher will also ask the English teacher's opinion about the students' improvement in speaking.

\section{Data Analysis}

To sustain the validity of the research result, the researcher collected data which were derived from several ways such as observation, interview, and tests. The researcher accomplishes the interview two times. First, the interview is conducted before applying the action research. In this case, the researcher interviews the English teacher concerning the teaching problem in that school, students' difficulties in learning the English language and what method is used by the English teacher. Here, the researcher found that the teacher uses dialogue memorization and text-based dialogue. Concerning the students' problem, students are the lack of vocabulary and motivation, so it is very difficult to make them practice the spoken language.

This interview is also conducted toward students in the second grade of SMPN 4 Praya Barat Daya regarding their difficulties in learning English especially speaking, the method that is used by their teacher, and the activities they do during the teaching and learning process. The interview remained that they are a lack of vocabulary, but they had the motivation to learn English furthermore to be able to speak English well. Sometimes they feel awkward and inconvenient, more and more when they have to take turns by turn to have a conversation with their partner in front of the class. From both interviews, the researcher infers that there are two main problems that bring about students' lack of speaking. First, students are lacking in vocabulary, second students are low in motivation. Therefore, they need something different in learning the English language to help them achieving the English language, especially in spoken language.

The observation was done by the researcher toward students of grade VIII of SMPN 4 Praya Barat Daya academic year 2019/2020 directly during the teaching and learning process. Here, the researcher as an observer observes the students behave in the classroom, for example, how students participate and achieve the speaking skill. The observation accomplished by using an observation form that has been formed by the researcher before. From the observation, the researcher found that the English teacher in teaching English only emphasizes on students' understanding of grammar and text genre. Meanwhile speaking is seldom taught by the teacher, and in teaching speaking, the teacher uses dialogue that students have to read it after the teacher. In practicing the dialogue, the teacher gets students to perform by using the textbook where the dialogue is written. Pair by pair student takes a turn and so until all the pair gets their turn. The number of students in which contains about 24 (twenty-four) students that make the class situation uncontrolled, so it needs extra monitoring toward students to behave. Dealing with both data; interview and observation, the researcher uses a triangulation technique that is an adjustment of data sources which is derived from the teacher, the students, and the real situation to ensure the validity of collected data.

According to David P. Harris (1998:178) test is considered as the best way to know how well students achieve the materials they have been learning. The objective of the test itself within the teaching and learning is to provide feedback (Penny Ur, 1992). Referring to 
those statements, from the feedback which gotten from students' test results (pre-test and posttest), the researcher can see the improvement of students' achievement in speaking skills. The test is conducted twice and is in the form of oral. First, it is a pre-test; a test which is given toward students before implementing the action research in order to diagnose students' ability in speaking skills. Second is the post-test; a test that will be accomplished to evaluate students' achievement and to know students' progress after implementing communicative language games in teaching English especially speaking skills within the classroom action research (CAR).

\section{RESEARCH FINDINGS AND DISCUSSION \\ Research Findings \\ Reconnaissance}

The research was started by gathering initial information from the English teacher and grade VIII students of SMPN 4 Praya Barat Daya. It was done by interviewing the English teacher and the students, observing the teaching and learning process, and conducting a pretest. The field problems which occurred during the teaching and learning process can be seen in Table 1.

Table 1

The Field Problems Found in the English Teaching and Learning Process

\begin{tabular}{|c|c|c|c|}
\hline No. & Field Problems & Indicators & Codes \\
\hline 1. & $\begin{array}{l}\text { The students had low motivation in learning } \\
\text { English, especially in speaking activities. }\end{array}$ & $\begin{array}{l}\text { The students did not pay attention to } \\
\text { the material delivered by the teacher. }\end{array}$ & S \\
\hline 2. & $\begin{array}{l}\text { The students looked apathetic and inhibited } \\
\text { to speak in English. }\end{array}$ & $\begin{array}{l}\text { They tended to keep silent when the } \\
\text { teacher was asking them questions. } \\
\text { Also, when the teacher asked them to } \\
\text { speak English, the students did not } \\
\text { want to speak up. }\end{array}$ & S \\
\hline 3. & $\begin{array}{l}\text { The students were afraid of making } \\
\text { mistakes when they spoke English. }\end{array}$ & $\begin{array}{l}\text { They said that they did not want to speak } \\
\text { English because they could not do it and } \\
\text { were afraid of making mistakes. }\end{array}$ & $S$ \\
\hline 4. & The students lacked vocabularies. & $\begin{array}{l}\text { They did not understand the } \\
\text { Teacher's talk in English. }\end{array}$ & $S$ \\
\hline 5. & $\begin{array}{l}\text { The students had low } \\
\text { pronunciation skill. }\end{array}$ & $\begin{array}{l}\text { They frequently made mistakes when } \\
\text { they were asked to pronounce English } \\
\text { words or to speak using English. }\end{array}$ & $\mathrm{S}$ \\
\hline 6. & $\begin{array}{l}\text { Many students interacted with the other } \\
\text { students and the teacher using their mother } \\
\text { tongue during the lesson. }\end{array}$ & $\begin{array}{l}\text { The students used Indonesian language } \\
\text { when they communicated with their } \\
\text { teacher and the other students during the } \\
\text { lesson. }\end{array}$ & $\mathrm{S}$ \\
\hline 7. & $\begin{array}{l}\text { Many students did not pay attention to } \\
\text { the teacher's explanation. }\end{array}$ & $\begin{array}{l}\text { They were busy with their own by } \\
\text { making noises during the class. }\end{array}$ & $\mathrm{TL}$ \\
\hline 8. & $\begin{array}{l}\text { The activities given by the teacher were } \\
\text { focused on reading and writing rather than } \\
\text { speaking skill. }\end{array}$ & $\begin{array}{l}\text { The teacher gave the materials by using a } \\
\text { course book that most of which were } \\
\text { related to the reading and writing } \\
\text { activities only. }\end{array}$ & $\mathrm{T}$ \\
\hline
\end{tabular}




\begin{tabular}{|c|l|l|c|}
\hline 9. & $\begin{array}{l}\text { The students lacked chances to practice } \\
\text { speaking during the lesson. }\end{array}$ & $\begin{array}{l}\text { The teacher often gave the students } \\
\text { activities which tended to relate reading } \\
\text { and writing skills by doing some tasks in } \\
\text { the worksheets or course book. }\end{array}$ & TL \\
\hline 10. & The media used were limited & $\begin{array}{l}\text { The media often used in teaching and } \\
\text { learning process were such as course } \\
\text { book, white board. }\end{array}$ & Md \\
\hline
\end{tabular}

Note:

$\mathrm{S}$ : Students

Mt : Materials

TL : Teaching and Learning process

$\mathrm{T}$ : Teacher

Md: Media

From the identified problems above, the researcher then decided some crucial problems that were feasible to solve as presented in Table 2.

Table 2

The Feasible Field Problems to Solve

\begin{tabular}{|r|l|c|}
\hline No. & \multicolumn{1}{|c|}{ Field Problems } & Codes \\
\hline 1. & $\begin{array}{l}\text { The students had low motivation in learning English, especially } \\
\text { in the speaking activities. }\end{array}$ & $\mathrm{S}$ \\
\hline 2. & $\begin{array}{l}\text { The students were afraid of making mistakes when they spoke in } \\
\text { English. }\end{array}$ & $\mathrm{S}$ \\
\hline 3. & The students were aphetic and inhibited to speak in English. & $\mathrm{S}$ \\
\hline 4. & $\begin{array}{l}\text { Many students interacted each other using their mother tongue during the } \\
\text { lesson. }\end{array}$ & $\mathrm{S}$ \\
\hline 5. & The students lacked chances to practice speaking during the lesson. & $\mathrm{TL}$ \\
\hline 6. & The students lacked vocabularies. & $\mathrm{S}$ \\
\hline 7. & The students had low pronunciation skill. & $\mathrm{M}$ \\
\hline 8. & The media used were limited & \\
\hline
\end{tabular}

The researcher began with the description of the improving students' speaking ability using communicative language games. The researcher presents the answers of the problem stated in chapter I, those are: "How does the use of communicative language games be able to improve speaking competence of the second year students of SMP N 4 Praya Barat Daya?" "To what extend communicative language games can improve the second year students of SMP N 4 Praya Barat Daya speaking ability?

To begin the research, the researcher and the English teacher discussed the essential problems to be solved. The students of Grade VIII had low speaking ability. It was shown by their being apathetic and inhibited to speak in English. As the result, the students felt afraid of making mistakes when they spoke in English. This condition absolutely obstructed the students' ability in expressing their ideas. Moreover, they tended to be passive in the speaking teaching and learning process. Also, they often pronounced some English words incorrectly when they were asked to speak in English. On the other hand, the students had less opportunity to practice their English orally. It can be seen from the teaching and learning activities which emphasized on doing reading and writing activities and seldom involved speaking activities.

From the observations and pre-test, the researcher noticed that the students often make mistakes in pronouncing some words. They also often make incorrect intonation. Besides, 
they were discouraged and still ashamed when they were asked to speak before the class. Moreover, most students were still unfamiliar with the use of English as a medium of instruction e.g. "Please, distribute the handouts.", "Who is absent today?", "Raise your hand". Based on those existing problems, the researcher needed to solve them to make the teaching and learning English processes run effectively.

After the actions had planned, acted, observed and reflected in the cycle 1, the following findings were found; (a) Communicative language games provided more opportunities to speak English and improved students' self-confidence and involvement. Besides, they decreased the students' anxiety and motivated the students to join the speaking class. Thus, communicative language games technique was generally successful in improving the teaching and learning of English speaking skill practices. (b) Classroom English was successfully used as an effort in improving the teaching of English speaking skill practices and in assisting the students to be more familiar with the English words. However some students still found difficulties in understanding English. Besides, they also needed to have translation in Indonesian. When the researcher was using English to teach, some of the students did not understand. They kept silent. Hence, using Indonesian translation was necessary for the students. (c) Language focus activities in terms of pronunciation, spelling and structure effectively helped to prepare the students in communicative focus activities like communicative language games. However, the pronunciation errors still frequently existed. (d) The use of varied themes in the cycle 1 could make the students enjoy their learning activities and reduce their boredom of joining the lesson. (e) Giving rewards by applauses and praises could motivate the students to be active or to speak up during the class. (f) Various media like handout, video, recording, LCD, pictures and flashcard successfully assisted the students learning process and made them enjoy their learning process. (g) Group works and pair works enabled the students interact each other. Besides, their self-confidence was improved. However, some efforts were still needed to modify the classroom management to make the students pay more attention and be ready to the lesson.

\section{Discussion}

\section{Cycle 1}

In this planning stage, the form of the pre-test and the communicative language games technique that would be applied in the first cycle were determined. Pre-test and post-test were used to know the students' achievement on their speaking ability. The researcher administrated the pre-test in the first meeting to the students. Both the pre-test and the post-test were designed in the form of performing dialogues based on given situation. In these tests, the students acted the dialogue they had made based on the situation given in front of the class. The researcher and the collaborator assessed their performance by using the speaking rubric adapted previously.

After determining the pre-test and the communicative language games technique, the teaching and learning instruments in terms of the speaking rubric, the lesson plans and the tasks were designed. Then, after all instruments of the research had been ready to be used, the action plans were carried out.

\section{Conducting Communicative Language Games}

Communicative language games were supposed to be the best solution to help the students improve their speaking ability. In the cycle 1, the games used were "Do me a favor" and "Shopping list". "Do me a favor" was a game given in the first meeting that involved the students to work in a group of four. Besides, in playing the game, they had to speak up using suitable expressions which had been taught. Every student in each group competed to finish the game fastest and become the winner. Meanwhile, "Shopping list" game was played by the students in the second meeting. In the game, there were two groups. Five students became the 
shop assistants and the others were the customers. The situation was made like in the shop. The students were asked to compete to be the first player who finished the game. For the shop assistant who was fastest selling all the things would be the winner while for customer who became the first player and got all the things they needed would be the champion. Therefore, to make them win the competition, they had to use suitable expressions which had been learnt and they had to speak up actively. The more detailed rules about the games can be seen in the handout in the appendix.

Conducting the communicative language games, the students were expected to have more opportunities to speak English referring to the activities during the games. Besides, they could motivate the students to join the speaking class because they found some fun activities in their learning process. Also, by using the games, the students' anxiety would be minimized and the students' self Confidence and involvement were gradually improved. As the result the students' speaking skill could be improved.

Using Accompanying Actions

Besides implementing communicative language games, some accompanying actions were needed to support the improvement of the students' speaking ability. The accompanying actions which were planned were as follows:

\section{Classroom English}

The purpose of using classroom English in the teaching and learning process was to make the students get familiar with the English pronunciation, grammar and vocabulary. Classroom English used was such as greeting the students in the beginning of the lesson, leading the materials that would be learnt, giving the instructions of the tasks or activities, explaining the materials, giving feedback and also ending the class. To avoid the students' misunderstanding when the classroom English was used, the researcher translated the language into Indonesian for the first time.

\section{Language Focus Activities}

Language focus activities captured three elements of language skills. They were related to the students' pronunciation, spelling, and grammatical structure. Pronunciation practice was done by imitating teacher's model or recorded model. The next language element, spelling, was practiced by doing blocks of letters or word search, completing words in the lexical web, and rearranging jumbled letters into words. Meanwhile, in the structure practice, the activities were rearranging jumbled words into sentences, matching, and completing sentences. Those form focus practices aimed at preparing the students in communication focus activities i.e. "Communicative language games". Thus, the students could speak using the expressions correctly and communicatively.

\section{Varied Themes}

The theme in the first meeting was "Do me a favor" that related to the expressions of asking, giving and refusing help that would be taught in the meeting, while in the second meeting, the theme applied was "Let's go shopping" that dealt with the topic of the lesson which was the expressions of asking, giving and refusing things. A variety of themes was still used to reduce the students' boredom with the lesson and those make them more enjoyable in learning the materials.

\section{Rewards}

One of the accompanying actions would be used in the cycle 1 was also giving rewards. The rewards given in the first and the second meetings were similar. They were applauses and compliments e.g. "Well done", "Very good". These were given to the students when they were willing to perform in front of the class voluntarily and also when they could answer the researcher's questions well. Generally, the rewards were used to appreciate the students who were active in the class. The purpose of this action was to extrinsically motivate the students to be active to speak up during the class. 


\section{Media Use}

Accompanying actions, especially using supporting media were necessarily applied in teaching the students. In cycle 1 , the media used were suchh as handout, LCD, recording, video, pictures, and flashcard. The use of media in the first meeting and the second meetings would be almost similar. The difference was that the first meeting used a video, while the second meeting used a recording. All the media had several functions for teaching the students. The LCD was used to show a video, pictures and power point. Besides, it was also used to play a recording. The media like video and recording were used to give the students comprehension focus of what they were learning. Meanwhile, the pictures were used to give the students a warming up or a brainstorming activity related to the theme which was discussed. To play communicative language games, the researcher always used flashcards.

Thus, by using all of the media mentioned above, it was believed that the students would be more enthusiastic and interested in joining speaking class. Besides, they would be more assisted in learning the materials.

Group Works

During cycle 1, working in groups or pairs in every meeting would be done by the students. Grouping was used to enhance the students' interaction among each other as well as to help them improve their self-confidence to participate in speaking class.

Action and Observation in the cycle 1

The pre-test was carried out in the first meeting on Wednesday, $28^{\text {th }}$ August, 2019. The actions which were implemented in the cycle 1 were conducted in two meetings. The first meeting was on Thursday, $29^{\text {th }}$ August, 2019 while the second meeting was on Wednesday, $4^{\text {th }}$ September, 2019. In this cycle, while the researcher implemented the action, the teacher took part in the class as the observer who observed the teaching and learning process by taking notes or fulfilling the observation checklist sheets.

\section{Cycle 2}

Cycle 2 was conducted in two meetings. The first meeting of cycle 2 was conducted on Thursday, September $5^{\text {th }}, 2019$. Meanwhile, the second meeting was conducted on Wednesday, September $11^{\text {th }}, 2019$. The communicative language games were implemented in every meeting as they were the main technique to improve the students' speaking ability. In addition, they were always linked-up with some accompanying actions. In this cycle, while the researcher was implementing the actions planned, the English teacher observed the teaching and learning process. The data during the cycle 2 were collected through classroom observation and interviews.

\section{Conducting Communicative Language Games}

The use of communicative language games as the main technique in this research successfully motivated the students. It was in line with Wright, Betteridge and Buckby (1984) who claim games as highly motivating activities that create enjoyment and excitement. Furthermore, based on the interview in the reconnaissance steps, some of the students were reluctant to speak English. They felt shy and afraid if they might make a mistake. Deesre (2002) says that games can create classroom environment in which students learn without realizing that they are studying. Learning activities were sometimes frustrating the students and made them less confident and inhibited to get involved in the learning process. Meanwhile, through communicative language games, they learnt in more fun way and unconsciously got involved in learning speaking process. With regard to that, communicative language games were successfully applied to make the students felt more confident in speaking English.

\section{Using Accompanying Actions}

The following are the reflections of the accompanying actions in the cycle 2 . 


\section{Classroom English}

The use of classroom English could be effective to improve the students' speaking ability and it made them more familiar with English words. Furthermore, it gave the students' more opportunities to speak English during the teaching and learning process. The students admitted that the classroom English was effective to improve the students' speaking ability. The translating into Indonesian and paraphrasing used by the researcher helped the students understand the difficult words or sentences.

\section{Language Focus Activities}

During the language activities, the students got involved in pronunciation, spelling and structure practices. Although some errors still existed when the practices were ongoing, the researcher gave the students another accompanying action. The action was giving feedback that would be discussed in the next part. Hence, the language focus activities were beneficial for the students to prepare the students in the communicative language games.

\section{Varied Themes}

Varied themes applied in the teaching and learning materials during cycle 2 were considered decreasing the students' boredom and making them enjoy the lesson. The themes were chosen based on the students' interest or commonly popular or familiar with them. The students' seemed to show that they enjoyed the materials. In addition, the English teacher also gave her comment related to the use of variety of theme.

\section{Rewards}

Based on the observation, the use of rewards in the forms of compliments, applauses, and presents was successful to improve the students' motivation and involvement during the teaching and learning process. The students became active in the class without being asked by the researcher. The compliments and applauses given by the researcher were kinds of rewards which could make the students feel satisfied because they had already succeeded in their performances. Meanwhile, rewards in the form of presents could make the students eager to compete with the other students because they want to get the present.

\section{Media Use}

Using some media like handout, flash cards, and pictures or LCD also motivated the students to join the speaking class. They became more enthusiastic in learning English. The media were necessary to make the students more enthusiastic in joining the speaking class. Furthermore, the media also assisted the researcher in delivering the materials communicatively. As the result, it was easier for the students to learn the materials.

\section{Group Works}

Related to the classroom management, pair works or group works improved the students' self-confidence when they were less confident in working individually. Group works were also the best solution to make the students interact each other. It is in keeping with Veldman et al. (2020) who state that pair works and group works can help students to improve their self-confidence to speak and become active learners.

\section{Rearranging the Students' Seating Arrangement}

Meanwhile, by rearranging the students' seating arrangement make the class condition better. It was done by separating the students who often made noises so that they could not chat with each other. Although it did not work optimally, it could minimize the class condition in which the students were not ready to join the lesson and they disturbed the other students. The English teacher stated her opinion about the students' condition. It is in line with what Haerazi, Prayati, and Vikasari (2019) do in their EFL classes in which seating arrangement in EFL classes can stimulate them to be autonomous and creative learners. 


\section{Giving Feedback}

The implementation of giving feedback to the students could be said successful to improve the students' English pronunciation and grammar. The students seemed enthusiastic to repeat some expressions or words after the researcher as the feedback of their pronunciation mistakes. Besides, the students became aware of the grammatical mistakes and could correct the mistakes after the researcher' feedback. In addition, the teacher stated that giving feedback to the Students' English pronunciation and grammar errors were effective to make the students aware of how to pronounce and how to create sentences correctly.

\section{CONCLUSION}

Based on the result of data analysis, the writer inferred that teaching English by utilizing cummunicative language games is effective and can improve students' speaking ability. It can be proved through several data such as: observation result which it showed the students enthuastic and actively participated in learning process. They were also motivated to learn spoken English which it reduces students' hesitation to say in English. From the result, the researcher concluded that there were the mean of pre-test is 59.75 while the mean of post test result is 75.42 . It means there are 15.67 impovement toward students' speaking score. From these interpretation, the writer obtained that there are $54.2 \%(87.5-33.3=54.2)$ of students score had improved after conducted post test in the second sycle, or 21 of 24 students are passed the KKM while the other three students are still bellow the KKM. It is meant that the implementation of communicative language games in the classroom action research to improve students speaking ability is success.

\section{REFERENCES}

Angelini, M. L., \& García-Carbonell, A. (2019). Developing English speaking skills through simulation-based instruction. Teaching English with Technology, 19(2), 3-20.

Asrobi, M, Seken, K, Suarnajaya, W. 2013. The Effect Of Information Gap Technique And Achievement Motivation Toward Students' Speaking Ability. e-Journal Program Pascasarjana Universitas Pendidikan Ganesha. Vol 1. Available at http://pasca.undiksha.ac.id/ejournal/index.php/jpbi/article/viewFile/7 36/522 (accessed 24/7/2019).

Berns, M. (2019). Expanding on the Expanding Englishes of the Expanding Circle. World Englishes, 38(1-2), 8-17. https://doi.org/10.1111/weng.12361

Bhatia, V. K. (2019). World Englishes in professional communication. World Englishes, 38(1-2), 30-40. https://doi.org/10.1111/weng.12362

Brown, H. D. 1994. Teaching by Principles: an Interactive approach to Language Pedagogy. Englewood Cliffs, NJ: Prentice Hall Regents.

Buhari, B. (2019). Practicing discussion in the form of pyramid to improve students' speaking performance and classroom interaction. Journal of Languages and Language Teaching, 7(2), 108-116. doi: https://doi.org/10.33394/jollt.v7i2.1958

Burns, A., and Joyce, H. 1997. Focus on Speaking. Sydney: National Center for English Lnguage Teaching and Research.

Burns, Anne. 1999. Collaborative Action Research for English language Teachers. United Kingdom: Cambridge University Press.

Celce-Murcia, M. (ed). 2001. Teaching English as a Second or Foreign Language, $3^{\text {rd }}$ edition.Boston, MA: Heinle \&Heinle.

Chen, I. (2005). Using games to promote communicative skills in language learning. TESL Journal, 11(2), February 2005. http://iteslj.org/Techniques/Chen-Games.html 
Chaney, A. L. and T.L. Burk. 1998. Teaching Oral Communication in Grades K8. Boston:Allyn and Bacon.

Deesri, A. (2002). Games in the ESL and EFL Class. The Internet TESL Journal, Vol. VIII, No. 9, September 2002. Available: http://iteslj.org/ http://iteslj.org/Techniques/DeesriGames.html

Fauziati, Endang. (2002). Teaching of English as a Foreign Language. Surakarta: Muhammadiyah University Press.

Haerazi, H., May Vikasari, R., \& Prayati, Z. (2019). The Use of Scientific-Based Approach in ELT Class to Improve Students' Achievement and Classroom Interaction. Register Journal, 12(2), 157-180. https://doi.org/10.18326/rgt.v12i2.157-180

Haerazi, H., Prayti, Z., \& Vikasari, R. M. (2019). Practicing contextual teaching and learning (CTL) approach to improve students' reading comprehension in relation to motivation. ENGLISH REVIEW: Journal of English Education, 8(1), 139-146. https://doi.org/10.25134/erjee.v8i1.2011

Hidayati, Y. (2019). The effect of storytelling towards students' speaking skill at X grade students of MA Nurul Haramain Boarding School. Journal of Languages and Language Teaching, 7(2), 132-143. doi: https://doi.org/10.33394/jollt.v7i2.1961

Kayi, H. 2006. Teaching Speaking: Activities to Promote Speaking in a Second Language. The TESL Journal, 12(11), http://iteslj.org/Articles/Kayi-TeachingSpeaking.html

Khodabandeh, F. (2018). The impact of storytelling techniques through virtual instruction on english students' speaking ability. Teaching English with Technology, 18(1), 24-36.

Mauranen, A. (2018). Second Language Acquisition, world Englishes, and English as a Lingua Franca (ELF). World Englishes, 37(1), 106-119. https://doi.org/10.1111/weng.12306

Reuben, B. D. 1999. Simulation, Games, and Experience-based Learning: The Quest for a New Paradigm for Teaching and Learning Simulation and Gaming, 30 (4), 498-505.

Richard , J C. \& Rodgers, T. S. (1986). Approaches and methods in language teaching. Cambridge: Cambridge Universit Press.

Richards, J. C. \& Renandya, W. A. (2002). Methodology in Language Teaching: An Anthology of Current Practices. New York: Cambridge University Press.

Richard, J. C. 2006. Communicative Language Teaching Today. New York: Cambridge University Press.

Veldman, M. A., Doolaard, S., Bosker, R. J., \& Snijders, T. A. B. (2020). Young children working together. Cooperative learning effects on group work of children in Grade 1 of primary education. Learning and Instruction, 67(July 2019), 101308. https://doi.org/10.1016/j.learninstruc.2020.101308

Wang, Y. W. (2010). Using communicative language games in teaching and learning English in taiwanese primary schools. Journal of Engineering Technology and Education, 7(1) 126-142. 